\title{
The First Record for Eudonia mercurella (Lepidoptera, Crambidae, Scopariinae) in Adana Province of Turkey and External and Female Genital Morphology of the Species
}

\author{
Erol ATAY ${ }^{1 *} \quad$ Levent EFIL ${ }^{2}$ \\ ${ }^{1}$ Department of Biology, Faculty of Arts and Sciences, Mustafa Kemal University, Hatay, TURKEY \\ ${ }^{2}$ Faculty of Agriculture, Dep. of Plant Protection, Çanakkale 18 March University, Çanakkale, TURKEY
}

\begin{abstract}
This study was conducted in field and laboratory. Eudonia mercurella was caught in forested areas in Adana (Kozan) with light trap. In the field studies, totally 4 female specimens were collected. Specimens were dissected in the laboratory and prepared female genitalia and wings slides. We described the external and female genital morphology of Eudonia mercurella in detail and also diagnostical morphological features. As a result of the study, Eudonia mercurella is a new record for Adana province.
\end{abstract}

Keywords: Adana, Lepidoptera, Eudonia mercurella, Crambidae, new record, Turkey

How to cite: Atalay, E. \& Efil, L. (2018). The first record for Eudonia mercurella (Lepidoptera, Crambidae, Scopariinae) in Adana province of Turkey and external and female genital morphology of the species. J. Anatolian Env. and Anim. Sciences, 3(3), 137-140.

\section{Türkiye'nin Adana İlinde Eudonia mercurella (Lepidoptera, Crambidae, Scopariinae)'nın İlk Kaydı ve Türün Dış ve Dişi Genital Morfolojisi}

Öz: Bu çalışma saha ve laboratuvar çalışmaları şeklinde gerçekleştirilmiştir. Eudonia mercurella, Adana Kozan ilçesinde ormanlık sahalarda ışık tuză̆ kullanılarak yakalandı. Saha çalışmalarında toplam 4 tane dişi toplanmıştır. Örnekler laboratuvarda preparat yapımı için hazırland, dişi genital ve kanat preparatları yapıldı. Eudonia mercurella 'nın dış morfolojisi ve dişi genital organları ayrıntılı olarak tanımlandı. Çalışma sonucu olarak Eudonia mercurella Adana ili için ilk kayıttır.

Anahtar sözcükler: Adana, Lepidoptera, Eudonia mercurella, Crambidae, yeni kayit, Türkiye

Atıf yapmak için: Atalay, E. \& Efil, L. (2018). Türkiye Adana İlinde Eudonia mercurella (Lepidoptera, Crambidae, Scopariinae)'nın İlk Kaydı ve Türün Dıș ve Diși Genital Morfolojisi. Anadolu Çev. ve Hay. Dergisi, 3(3), 137-140.

\section{INTRODUCTION}

The Scopariinae which belong to the Crambidae (Pyraloidea) comprise 530 species occurring predominantly in the temperate zones of the northern and southern hemispheres, on occeanic islands and at montane and alpine elevations of the tropics. The Scopariinae subfamily is classified into 21 genera worldwide (Nuss, 2003). Eudonia was established by Billberg in 1820 with Phalaena mercurella Linnaeus, 1758 as the type species. It contains 252 described species worldwide (Li et al., 2012). Weichun (2012) reports this number as 261 in his other article. The members of the genus Eudonia can be recognized by the long and thin costa, the absence of free distal process and cornutus in the male genitalia; the long and thin apophysis posterior and apophysis anterior, the elongate colliculum and the presence of appendix bursae in the female genitalia (Weichun, 2012). According to Medvedev (1997), morphological characteristics of the genus; antennae filiform; labial palps densely scaled; maxillary pals with bruh of scales; forewings narrow; on hindwings $\mathrm{M}_{2}$ and $\mathrm{M}_{3}$ originate from single point or on short stalk.

There are seven species belonging to the genus Eudonia in Turkey (Koçak \& Kemal, 2009). The first attempt on the checklist of the Turkish moths were listed by Koçak \& Kemal (2006, 2007). Totally 4604 moth species were listed together with their synonymous named and updated provincial distributions. Later, the authors (Koçak \& Kemal, 2009) reported that the Turkey Lepidoptera fauna was 5128 species belonging to 76 families. In addition, a total of 692 lepidoptera species, 506 Heterocera and 186 Rhopalocera, belonging to the province of Adana were listed by the same authors. The species belonging to the genus Eudonia are not found in Adana. Eudonia mercurella is new record for the the lepidoptera fauna of Adana. 


\section{MATERIALS AND METHODS}

Field Studies: Field studies were carried out in forested areas in Adana (Kozan) province in June-August 2017. All the field works were done under suitable weather conditions (without precipitation and strong winds), and works started early in the morning and continued until sunset. Eudonia mercurella was caught in forested areas in Adana (Kozan) with light trap. In the field studies, totally 4 female specimens were collected.

Laboratory Studies: Before they were losing body water, the collected specimens were sorted according to body sizes, and were needed with a number zero insect needles that matched the size of the custom sized boards, strain and inhibition couples were strained in laboratory work. For the drying of the stretched specimens, they kept at room temperature for two weeks in a dark and dry place. Female genital organ was prepared for the identification of the species following morphological examinations and measurements on the male specimens. The needling of the butterflies, stretching of the wings and genital organ preparations were done accordingly the methods which defined in Atay (2006). The major taxonomic characters described. Important morphological organs of Eudonia mercurella were photographed and drawn. The specimens stored at the Biology Department of Mustafa Kemal University in Hatay.

\section{RESULTS AND DISCUSSION}

\section{Genus Eudonia Billberg, 1820}

Syn: Eudonia Billberg, 1820; Boiea Zetterstedt, [1839]; Witlessia Chapman, 1912; Eudoria Marion, 1959; Toulgoetodes Lerout, 1988 (Koçak \& Kemal, 2009).

\section{Eudonia mercurella (Linnaeus, 1758) (Pyralidae)} Figure 1.

Syn: Scoparia mercurea Howorth, 1811, Lep. Brit., p. 499; Eudorea frequentella Stainton, 1859, Mn. Brit.Butt. Moths, 2, p. 162 (Hannemann, 1964).

The distribution of Eudonia mercurella in Turkey; Balıkesir and Trabzon (Koçak \& Kemal, 2009).

The distribution of Eudonia mercurella in the world; Norway, Denmark, Sweden, Finland, East Europe, Estonia, Litvia, Lithvania, Poland, Czech Republic, Slovakia, Germany, Netherlands, England, Irland, Belgium, Luxemburg, France, Spain, Portugal, Corsica, Sardinia, Sicily, Italy, Switzerland, Austria, Hungary, Romania, Bulgaria, Albania, Greece, Crete (Karsholt \& Razowski,
1996); Middle Europe, Span, Dalmatia, Greece (Hannemann, 1964).

\section{Material Examined}

Horzum-Kozan-Adana-Turkey $\quad\left(37^{\circ} 37^{\prime} 25^{\prime \prime} \quad \mathrm{N}\right.$; 3551'14" E, 780 m.); 25.VI.2017 1; 10.VII.2017 2羊; 25.VII.2017 1우

\section{Measurements of the Adults \\ Body Length + : 7.5-8 mm. \\ Wingspan + $16-19 \mathrm{~mm}$.}

Female (Figure 1): On the head vertex and frons pale brown mixed with white. Labial palps well developed, very long, first segment strongly recurved upwards and the second and third segments extend straight reaches, densely scaled, pale brown, dorsally mixed with white; ventral completely white. Maxillary palps pale brown mixed with white. Antenna pale brown on dorsal surface, beige and brown on ventral surface. Haustellum is well developed, quite long and with dirty white. Eyes are round, large and dark brown. On the head ocelli well developed.

Head is 1.4 times wider than its length. Antennae filiform and medium length, densely covered with short cillia, its length 0.7 times longer than forewing length (Figure 2).

On the thorax is yellowish brown mixed white scales; the ventral of thorax is white.

Forewings are long and narrow, its length 2.9 times longer than its width. The ground color of the forewing light brown with small yellow and white stains; antemedian line white and very narrow; postmedian line and subterminal line white and very narrow; especially the whitish $\mathrm{X}$ in the terminal region formed by the meeting of the postmedian and subterminal lines. Fringe is long and light brownish white, brown near base. The ventral surface of the forewings pale brownish beige. Hindwings are quite broad and its length 1.7 times longer than its width. The ground color of the hindwings brownish beige; outward covered with pale brown scales. Veins of forewing and hindwing of Eudonia mercurella are as in Figure 3.

The female genital organ is as in Figures 4 and 5.

Papilla anales is not sclerotized; with weak and sparse hairy. Apophyses posterior and apophyses anteriores are almost the same length. Ostium sclerotized, small and oval shaped. Ostium bursae sclerotized and short. Ductus bursae sclerotized, very long and narrow. Corpus bursae broad and oval shaped, weakly sclerotized. Signum water drop shaped, comprising numerous spines on the its wall. 
In this study, we described the external and genital morphology of the female E. mercurella. The important taxonomic characters belong to E. mercurella were described in detail by comparasion of different parameters with each other. Each one of the external and genital taxonomic characters were measured with digital caliper and stereo microscope. This species is new record for the the lepidoptera fauna of Adana.

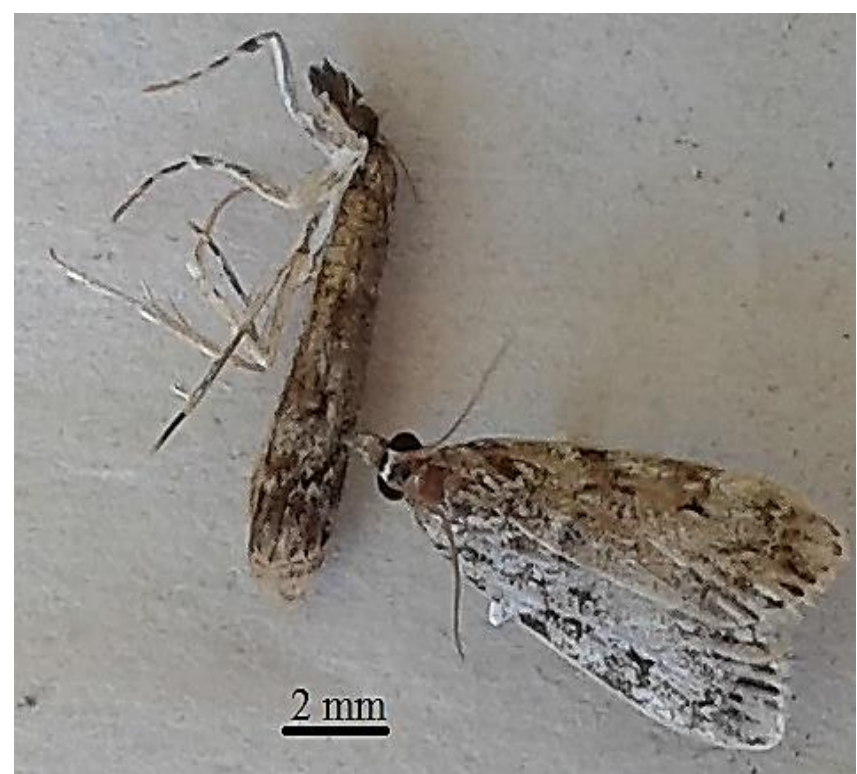

Figure 1. Adults of Eudonia mercurella.

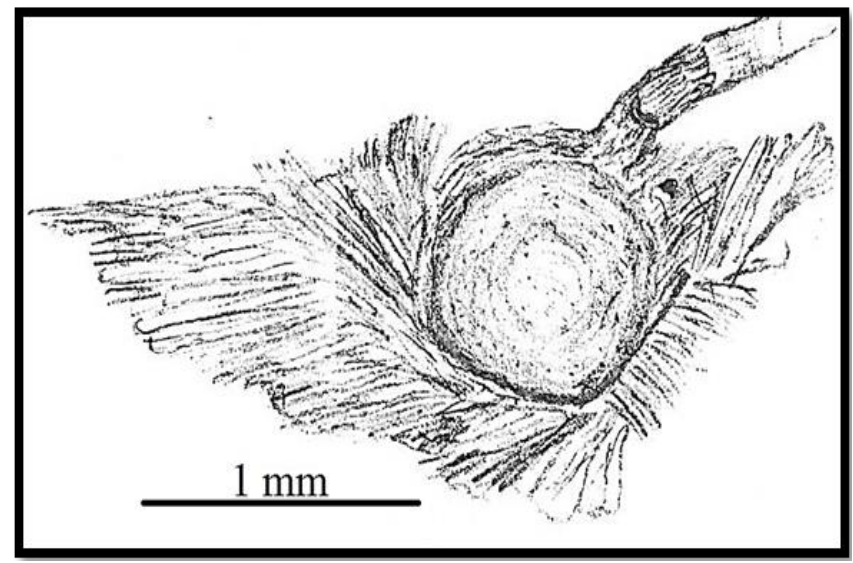

Figure 2. The head structure of Eudonia mercurella.

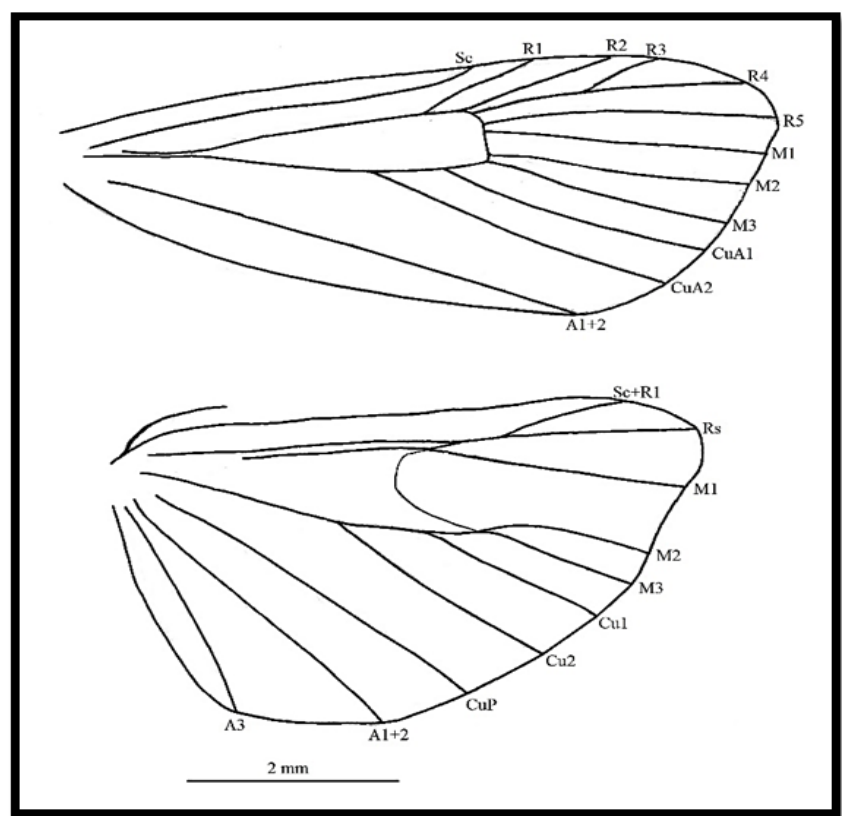

Figure 3. Veins of forewing and hindwing of Eudonia mercurella.

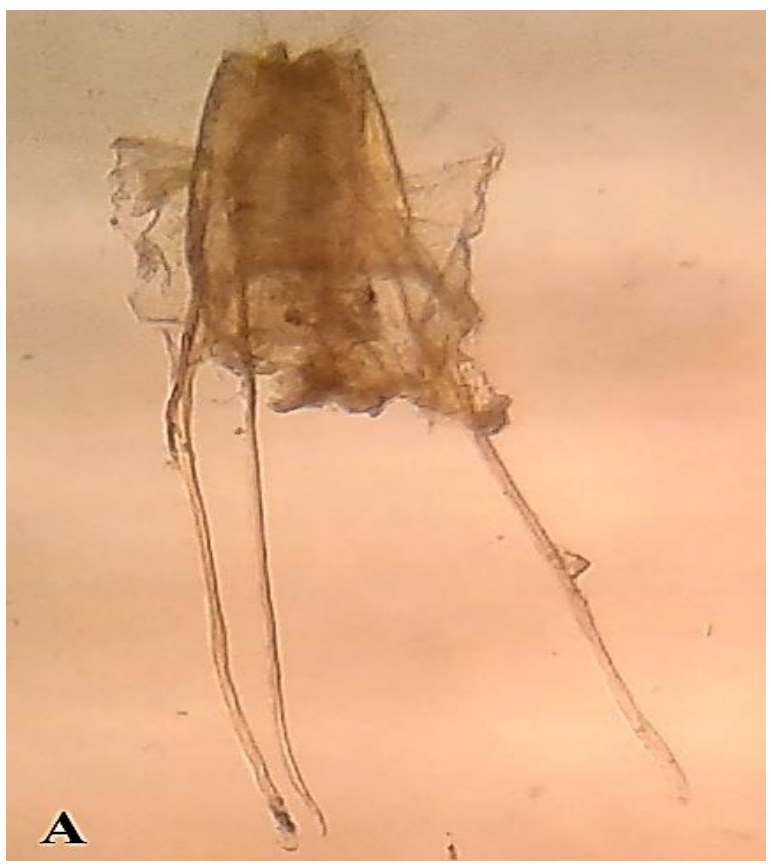

Figure 4. The Female Genitalia of Eudonia mercurella (Papilla anales, Apophyses posterior, Apophyses anteriores).

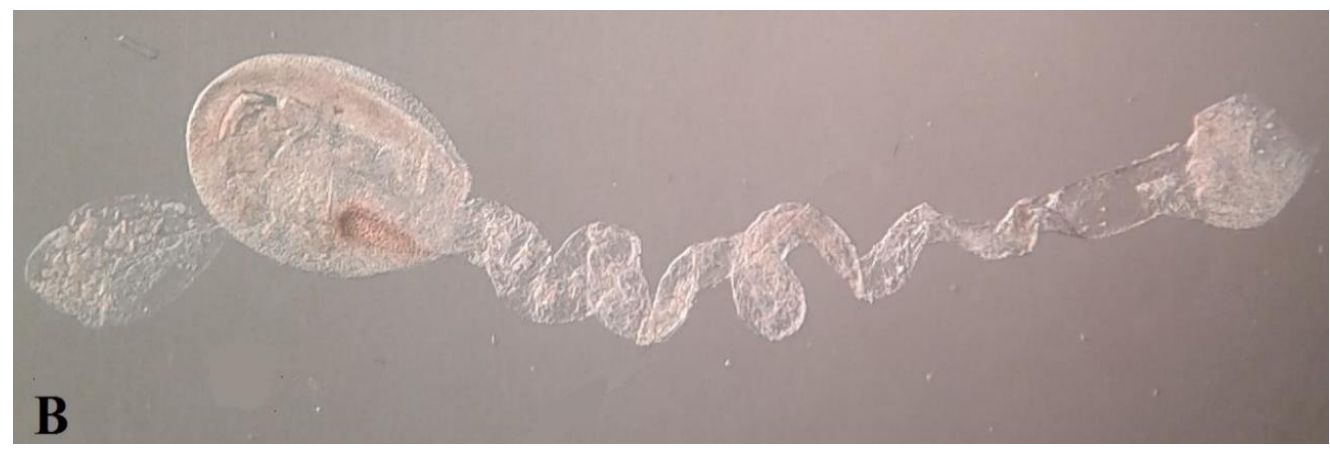

Figure 5. The Female Genitalia of Eudonia mercurella (Ostium, Ductus Burasae, Bursa Copulatrix, Signum). 


\section{REFERENCES}

Atay, E. (2006). The identity of Parapoynx affinialis (Guenée, 1854) (Lepidoptera, Crambidae, Nymphulinae) in Turkey. Journal of Entomology, 3(1), 76-81.

Hannemann, H.J. (1964). Die Tierwelt Deutschlands und der Angrenzenden Meeresteile nach ihren Merkmalen und nach ihrer Lebensweise. Kleinschmetterlinge Oder Microlepidoptera. Veb Gustav Fischer Verlag, Germany, 403 pp.

Karsholt, O. \& Razowski, J. (Eds.). (1996). The Lepidoptera of Europe: a distributional checklist. Brill Academic Pub.

Koçak, A. Ö. \& Kemal, M. (2009). Revised checklist of the Lepidoptera of Turkey. Centre for Entomological Studies Ankara, 17, 1-150.

Koçak, A.Ö. \& Kemal, M. (2006). Checklist of the Lepidoptera of Turkey. Centre for Entomological Studies Ankara. 1, 1-196.

Koçak, A.Ö. \& Kemal, M. (2007). Revised and annotated checklist of the Lepidoptera of Turkey. Priamus. Serial Publication of the Centre for Entomological Studies Ankara, 8, 26-42.

Li, W., Li, H. \& Nuss, M. (2012). Taxonomic revision of the genus Eudonia Billberg, 1820 from China (Lepidoptera: Crambidae: Scopariinae). Zootaxa, 3273, 1-27.
Medvedev, GS. (1997). Keys to the Insect of the European Part of the USSR. Science Publishers, USSR, 690 pp.

Nuss, M. (2003). Afroscoparia-a new genus of Scopariine from southern Africa (Insecta: Lepidoptera: Pyraloidea: Crambidae).

Weichun, L. (2012). One New Species of The Genus Eudonia Billberg (Lepidoptera: Crambidae: Scopariinae) from China. Entomotaxonomia, 34(2), 267-269.

Received date: 09.06 .2018

Accepted date: 15.10 .2018

\section{*Corresponding author's:}

Erol ATAY

Department of Biology, Faculty of Arts and Sciences, Mustafa Kemal University, Hatay, TURKEY

E-mail: eatay@mku.edu.tr

ORCID: https://orcid.org/0000-0002-5274-1025 